\title{
The state of functioning transport, freight forwarding and logistics companies and their responses to the pandemic crisis
}

"The world has accelerated, and with it all the good and the bad has accelerated as well". Scott Galloway

Klaudia Furtak, M.Sc., University of Zielona Góra,

Faculty of Economics and Management, Institute of Quality Science and Management, Department of Controlling, Poland, ORCID: 0000-0003-2268-8152.

\section{Introduction}

Polish economy has not experienced such a sudden and major shock as the one brought on by the COVID-19 pandemic since the systemic transformation of 1989, or even earlier, since the Great Depression (1929-1933). The situation that arose was new for company owners, managers as well as politicians, requiring a multi-faceted analysis and diagnosis in order for people to keep functioning and make rational decisions that would minimalize its negative effects.

The economic crisis caused by the emergence of the new disease has afflicted almost all countries in the world, including Poland. It has left a major mark on the entirety of the social, economic and cultural life, whose quality has dropped considerably.

On the basis of the existing survey research (questionnaires, interviews) conducted during the initial phase of the pandemic (from March to April of 2020), subject literature, various 
internet data (opinions, comments, research reports, discussions), personal experiences and observations as an employee of an international TFL company, the author will attempt to describe the type of the impact the pandemic has had on the TFL companies as well as companies in other fields (paper, automotive and food industries, etc.). The author will also present the responses of transport and logistics enterprises to the pandemic crisis. The justification for the studies has already been presented in the first paragraph of this article, however, it should be added that the research may constitute a starting point for an analysis of the dynamics and scope of changes, which will be identifiable in subsequent surveys. Documenting the results of a phenomenon so disastrous and unusual as the COVID-19 pandemic is a duty of not only the academic and scientific circles, but also the direct witnesses and participants of this tragedy.

The author bases her approach to the issue on the general assumption that the influence of coronavirus on the functioning of TFL companies has not been uniform. And although, unquestionably, its most perceptible, negative and destructive force predominates, the existence of a positive impact, as a factor that accelerates and revives company development, is not impossible. This opinion is shared by numerous Polish and foreign scholars researching this phenomenon. The author of the article is more moderately optimistic, rather formulating hypotheses than categorical claims. This methodical caution appears justified in this case, since it is not certain whether the phenomena described as positive influences of the pandemic on businesses will turn out to be favourable to their development and technological progress. Other factors that hinder the economic development may emerge.

The data collected for the purpose of writing this article was divided into the following subjects:

- the essence of the economic and financial crisis, and its triggers - theoretical perspective,

- micro-companies, small companies and medium companies amid the COVID-19 pandemic,

- functioning of transport, freight forwarding and logistics companies during the pandemic,

- the responses of companies to the pandemic crisis.

\section{The essence of the economic and financial crisis, and its triggers -theoretical perspective}

Crisis appears to be one of the most commonly used words in modern times. It is an inherent element of daily information, on both the national and international 
level. Colloquially, it is used to describe situations wherein the common denominator is the aspect of risk or threat. Therefore, there exists a crisis of values, a crisis of family, a crisis of public finances, a crisis of terrorism, a crisis in international relations. The origin of the notion is ancient (Greek): krinein means to divide, decide and judge, and its derivative noun krysie is defined as a selection or a decision (Szlagura, n.d.). English dictionaries exemplify crisis as a turning point during an illness, a decisive moment especially during a tragedy, a time of danger, a climax (Webster's..., 1957). Winston Churchill, a British prime minister, claimed that each crisis resembles mistakes - it teaches people something new and no lesson it - or each subsequent crisis - provides should be wasted (Czech et al. 2020).

After juxtaposing the original, ancient meaning of the word crisis with its modern pejorative understanding, it turns out that it has undergone a major evolution, broadening its semantics by such qualities as suddenness, traumatism and the subjective consequences of trauma in the form of negative experiences. This notion appears in relation to numerous aspects of human life and society. A crisis can be caused by a negative event, for instance a stock market crash, a dispute, a death, a misunderstanding within a coalition. However, as it has already been mentioned, it can also be an outcome of mass occurrences such as wars or pandemics.

From a psychological perspective, a crisis is the state of our psyche with a high level of emotional tension, largely perceived as a state of fear or psychological imbalance (Gerrig and Zimbardo, 2006).

One of the most famous concepts describing a crisis and its significance for an individual was presented by E. Ericson (Babczyński, n.d.). The psychologist claimed that the conflicts between an individual's urges and the newly-appearing requirements of the environment constitute crisis-making mechanisms. Yet another author, Ż. Płużek (1991), provides the following definition of the phenomenon: "(...) a crisis signifies a healthy human's reaction to a difficult situation, wherein the ability to solve problems cannot be used, since it has become insufficient. There are no prepared methods of coping and, therefore, the phase of searching for a solution begins".

The notion of the pandemic crisis used in the article denotes the consequences caused by the spread of the pandemic virus on a global scale.

However, the fundamental subject of this section of the article is the essence of the economic crisis and its triggers, discussed below.

From the economic perspective, a crisis can be defined as an economic slump, a phase of the economic cycle distinguished by decreased production, investment outlays, the society's real incomes, accompanied by increased unemployment 
and, occasionally, lower prices (Czech et al. 2020). According to Shaikh (1978), a crisis is a set of economic failures. Rothbard (2010), on the other hand, considers a crisis a result of wrong investments and wrong decisions.

In subject literature, there is no unanimous view on the method of defining a financial crisis. Bordo and others (2001) perceive a financial crisis as an episode of guaranteed changes on financial markets, related to insufficient liquidity or even bankruptcy of some market participants and the interventions of the authorities of the public sectors aimed at preventing this. A crisis paralyses financial institutions and leads to a sudden outflow of the capital. It introduces real economy in times of recession.

Reinhart and Rogof (2008) enumerate five fundamental factors (variables) that trigger an economic crisis:

1. Foreign mistakes - with incorrect fiscal, monetary and macroeconomic policies both directly and indirectly influencing the economic situation of related countries, mostly with regards to trade and financial relations.

2. National mistakes - with incorrect monetary policy, no transparency in fiscal policy and too large public debt.

3. Bank crises, caused by, for instance, lower liquidity of the international market triggered by a sudden loss of faith in financial institutions and insufficient liability securities.

4. Currency crises, involving a sudden outflow of foreign capital resulting in a major depreciation of the national currency. Currency crises are most often believed to be caused by a sudden loss of trust in a given currency, which results in its further depreciation. It is frequently and correctly emphasised that economic theory gives no explicit answer to the question about the causes of currency crises. In the first generation model, the source of the crisis is mostly an unjust and unreasonable fiscal policy of the given country. In the second generation model, a crisis is caused by a speculative attack on the national currency. According to the third eclectic model, a crisis is caused by structural weaknesses of a country and mistakes made on a microeconomic level.

5. Excessive inflation - with sudden price reductions influencing, for instance, a sudden increase in interest rates. Obtaining a higher cost of foreign capital for investments limits economic growth and, in the long term, can even contribute to recession. Moreover, a high inflation rate also means a quick decrease in the time value of money.

All economic crises are characterised by, among others, a slowdown in the economic growth, decrease of real earnings, decrease in the consumption 
level and major decrease of investments. During an economic crisis, the inflation rate increases, the economic condition of the country deteriorates, the budget deficit and public debt increase, tax rates are increased to produce more money in order to finance the costs of the crisis. On the microeconomic level, the destructive effects of the crisis include, above all, the collapse of production and trade companies as well as banks. Asset value visibly decreases. The demand for both national and international goods decreases as well.

When studying the influence of the COVID-19 pandemics on the economic situation of the country, experts wonder if it would not be better to refer to a broader notion of a crisis. Hordecka (2017) associates with it not only the decrease in economic growth, but also an increasing imbalance in terms of incomes and opportunities, a growing instability of the financial sector, environmental issues, and, finally, also the degeneration of the social, human and moral capitals. The researcher claims that in light of the current challenges, it is crucial to adopt a correct economic policy. It is even possible that a paradigm change might occur on the global scale, involving a departure from the traditional politics, based on neoclassical economics with elements of Keynesian economics, and towards a heterodox economic policy.

Behavioural economics plays an important role in the understanding of the essence of crises (Zygan, 2013). According to Argouleas (2009), most causes of crises are a result of behavioural factors. Unfavourable information which puts a person in face of danger, e.g. losing a social position, wealth, health etc., causes various types of anxiety. When in danger, the so-called herd effect, crowd psychosis and irrational mass behaviours often occur.

The COVID-19 pandemics, which constitutes the subject of the research for this article, is an example of extreme danger which can lead to an environmental, economic and social crises. Włodarczyk (2011) claims that the removal of negative consequences of the crisis should take two simultaneous paths - firstly, by actions aimed at restoring economy and compensating for material losses, and secondly, by actions aimed at decreasing the effects that are psychological in nature.

The information presented in the article does not fully answer the question of what are a crisis, its essence and its characteristic features. It merely identifies several theoretical aspects associated with the notion. There are many descriptions, theories and definitions of such situations in the subject literature. This text, in the context of the whole article, constitutes a background for the fundamental notions discussed in the article. 


\section{Micro-companies, small companies and medium companies amid the COVID-19 pandemic}

Scientists from the Polish Academy of Sciences wrote in their synthetic work on the essence of COVID-19 and its economic effects that in the second quarter of 2020, GDP decreased by $8-9 \%$, and by the end of the year it would have decreased by $4.5 \%$ in comparison with the previous year (Duszyński et al. 2020). Their predictions for 2021 show an increase by $4.23 \%$, which means that after the pandemic it will take some time for Poland to return to the previous path of growth. This conclusion is in accordance with the predictions made by Paweł Bukowski and Wojciech Paczos, economists of the Institute of Economics, in April, 2020:

Mechanical losses of a month-long hibernation total less than 1.1\% of an annual GDP. The longer the hibernation period, the bigger the losses - aside from the typical summation, additional effects will emerge, on the one hand due to the insecurity and need to save up and, on the other, as a result of the domino effect (losses in subsequent lines of business) as well as bankruptcies and unemployment. A three-month hibernation may result in losses of up to $10 \%$ of annual GDP(Bukowski as cited in Duszyński et. al, 2020, p. 30).

The economic downturn has brought on the risk of a wave of bankruptcies, unemployment and long-term recession. The initiatives of public administration, known as anti-crisis shields (in Polish: tarcze antykryzysowe), have undoubtedly been costly, but justified and similar to the initiatives undertaken by developed countries facing the crisis. The European Union made a decision to give 750 billion $€$ to its member states in order to help them fight the crisis and its effects. Poland can use a large percentage of its share for the above-mentioned purpose. $\mathrm{PwC}$, SpotData and the research company CBM Indikator have conducted a survey at the turn of March and April of 2020. Its purpose was to diagnose the first effects of COVID-19 on enterprises (Polski, mikro, mały i średni..., 2020). The research utilized the method of telephone surveying (CATI technique) and online questionnaires, with the participation of a sample of more than 750 micro-companies, small and medium companies. The purpose of the study, according to its organisers, was to capture the first reaction of enterprises to the situation related to the pandemic. The study attempted to find answers to the following questions: What are the difficulties faced by company owners? Which actions were taken first to combat the effects of the virus? What is the situation of the company in terms of financial liquidity? What undertakings are planned in relation to the current situation? 
Without analysing the answers in too great a detail, certain general decisions and conclusions revealed by the surveys should be emphasized. Those are: Almost $90 \%$ of Polish companies detect difficulties due to social isolation and change in customer behaviours. In more than one-third of the companies (35.5\%) the decrease in income exceeds $50 \%$ in comparison with a similar time period in the previous year. This is a situation that has not been faced by companies since the systemic transformation of 1989. At the peak of the financial crisis, in the first half of 2019, the general decrease of income in companies with less than 250 employees did not exceed several percent per year, according to the data provided by the Central Statistical Office of Poland (GUS). Therefore, the impulsiveness of the current disturbances is incomparable to the events that occurred earlier in the history of Polish market economy.

The greatest decrease in income was recorded in companies with 2-9 employees (micro-companies). Income decreased by more than $50 \%$ in almost half of the companies of this group. Still, it does not mean that bigger enterprises are safe. Every fifth company with 50-249 employees and every third small company (with 10-49 employees) face the problem of rapid decrease of income by more than $50 \%$.

Aside from income decrease, another important problem involved delays in payments from customers. More than $50 \%$ of enterprises experienced issues with financial liquidity. The problem was enormous even in these branches of economy that were not in the front line attacked by the crisis. For example, almost $70 \%$ of industrial companies reported issues with payment delays.

Companies in the sector of consumer services were the most affected by the pandemic, while construction companies and business services were relatively the least affected. In the survey on consumer services, every single company experienced income decrease, while more than $60 \%$ feared that income would decrease by more than $50 \%$ in comparison to the previous year. Few companies in the remaining sectors were unafraid of lower income: $17 \%$ in construction, $15 \%$ in business services, $7 \%$ in industry and $6 \%$ in commerce. $35 \%$ and $41 \%$ of companies in the sectors of industry and commerce, respectively, predicted a decrease of income by more than $50 \%$. Responses to questions on the ability to maintain financial liquidity in companies were analogous in structure.

No visible difference was observed between the situation of companies that trade internationally and those that operate only on the Polish market. The ones in circumstances greatly below average were importers. This was probably not the result of impediments to international trade. Exporters were in a situation relatively better than importers, probably due to the fact that among exporters 
there are more construction companies and business service companies. Other possible reasons for this status include the weakening of the Polish zloty and lower demand for imported goods other than necessities.

In response to the economic shock, one-third of companies limited employment. The highest number of such businesses was among small companies $-42.5 \%$. One-fourth of medium companies, with 50-249 employees, began to dismiss employees early on in the pandemic, while some companies were only planning dismissals. This confirms the conclusion that the smallest companies experienced the greatest economic shock, while bigger companies were more resistant to short-term shocks.

Most enterprises (59.3\%) were not able to maintain financial liquidity without dismissing employees for longer than three months at the beginning of the pandemic.

\section{Functioning of transport, freight forwarding and logistics companies during the pandemic}

The TFL field is one of the most important in our economy. It integrates three sectors: transport, freight forwarding and logistics. Its main purpose is the complex management of goods transport both within country borders and internationally. Its customers mostly include large production companies that sell their goods on the national and international markets, but also e-commerce companies or even private persons. Prior to the outbreak of the pandemic, these services ensured that a given parcel would reach its destination on time.

TFL is a huge sector of Polish economy, responsible for producing $6.5 \%$ of GDP. The value of internal logistics, whose purpose is to fulfil the companies' own needs, is $80 \%$ of the whole TFL sector. Therefore, it is estimated that the whole Polish TFL sector is responsible for the production of almost $12 \%$ of GDP. (Zysińska, 2019, pp. 143-144). This is also confirmed by Eurostat data.

The operations of these companies were largely limited and disturbed due to the destructive influence of the coronavirus on their functioning. In the first weeks after the outbreak of the pandemic (April-May, 2020), transport companies faced a major challenge to ensure the continuity of operations, chains of delivery, as well as limit and minimize the ramifications of the crisis. The responses of companies to both the local and global economic slowdown as well as specific projects aimed at reducing the effects of the crisis may become the reason for economic recovery through the introduction of new technologies and management methods. 
The DGC company, hired by the Eurologistics publisher, conducted a survey among the logistics and transport companies. Its purpose was to report the conditions on the market of logistics services as they changed in the first weeks after the outbreak of the pandemic. According to the authors of the survey, the research focused on three issues: the actions undertaken by logistics companies to ensure the continuity of operations in the pandemic conditions, the risks faced by logistics companies and the level of activeness of individual companies in purchasing logistics services.

The following effects of COVID-19 have had a strong destructive impact on the functioning of transport and logistics companies and other factors including political, economic and social:

- decrease in demand for services - $46 \%$,

- payment hold-ups - $46 \%$,

- broken chains of international deliveries $-45 \%$,

- burden of tax liabilities - $42 \%$,

- burden of financial obligations - $41 \%$,

- change in supply structure $-28 \%$,

- restrictions due to closed borders $-21 \%$,

- broken chains of national deliveries - 19\%,

- disturbances in transport (traffic restrictions, sanitary inspections) - 17\%,

- unavailability of correct transportation - $14 \%$,

- change in the structure of the demand for services $-14 \%$,

- shortage of employees - 7\%,

- lower shipping rates $-6 \%$.

The influence of the coronavirus pandemic for the results of the activity transport companies in 2020r. confirm also date from GUS and US in Szczecin. This publication (Transport - wyniki działalności w 2020r.) has been prepared on the basis of the results of the public statistics survey, with the use of administrative data of the Ministry of Digitalization (the Central Register of Vehicles), the General Directorate for Public Roads and Motorways, the General Police headquarters, and the Civil Aviation Office, as well as the data of the European Commission and the Statistical Office of the European Communities (EUROSTAT).

Here are some findings from this publication. Data regarding economic entities classified into section $\mathrm{H}$ "Transportation and Storage" with the exclusion of entities classified into division "Postal and Courier Activities".

1. Revenues from the sale of services in all transport entities were lover by $1,2 \%$ in comparison with 2019 and amounted to PLN 280,6 billion (in the public 
sector decreased by $17,6 \%$ and in the private sector increased by $1,4 \%)$. The share of enterprises employing more than 49 persons accounted for $42,5 \%$ of total revenues and the decrease in the sale of services in these entities were lower by $4,9 \%$.

2. Prime costs of sold services in all transport entities amounted to PLN 260.6 billion and grew by $0.8 \%$ in comparison with 2019 (in the public sector decreased by $18.1 \%$, and in the private sector increased by $3.0 \%)$. It decreased by $3.3 \%$ in entities employing more than 49 persons (the share of these entities in the total costs amounted to $45.8 \%$ ). In the total structure of costs by type, an increase gross remuneration including employee benefits (by 1.5 percentage point), depreciation (by 0.6 percentage point), in the third party services (by 0.4 percentage point), taxes and fees (by 0.1 percentage point), a decrease in the share of materials and energy consumption (by 2.4 percentage point) and other costs (by 0.2 percentage point).

3. The gross financial result generated by entities employing more than 49 persons amounted to PLN 2 859.9 million in 2020, (compared to PLN 5478.8 million in 2019) and it was $47.8 \%$ lower than last year and the net financial result decreased from PLN 4375.6 million in 2019 to PLN 1980.2 million in 2020 (by $54.7 \%$ ). The cost level indicator for total activity amounted to $97.9 \%$ (compared to $96.2 \%$ last year). The following indicators increased: the cost level indicator on the sale of services from $98.4 \%$ in 2019 to $100.1 \%$ in 2020 , indicator decreased the gross turnover profitability indicator from $3.8 \%$ to $2.1 \%$, and the profitability indicator net turnover - from $3.0 \%$ to $1.4 \%$.

4. The average paid employment 1 on the basis of employment contract amounted to 658.2 thousand persons in the whole transport sector in 2020 and was lower by $0.1 \%$ in comparison with 2019 (decreased by $2.1 \%$ in the public sector and by $0.6 \%$ increased by in the private sector).

5. All modes of transport carried 2613.8 million tonnes of goods, which is $17.7 \%$ more than in the previous year and the transport performance amounted to 540.5 billion tonne-kilometres, which is $13.3 \%$ more than the last year. The increase of carriage of goods was noticed in road transport, while the decrease was observed in rail, air, pipeline, inland waterways and maritime transport. The transport performance grew only in air and pipeline transport.

6. the public transport fleet 2 carried 373,8 million passengers, which is $45.6 \%$ less than in the previous year. The decrease in the carriage of passengers was noted in air transport (by 83.4\%), in road transport (by 51.2\%), inland waterways (by 49,9\%), in rail transport (by 37.8\%) and maritime transport3 (by $31.5 \%$ ). The performance of passenger transport amounted to 27,6 billion kilometres and was lower by $66.6 \%$ compared to the previous year. 
The list does not encompass all effects and consequences of the pandemic on TFL companies. There were, and still are, many more. Direct observation road transport alone made it possible to notice such phenomena as completing shipping documentation electronically (through e-mail), lack of teamwork due to work from home, which, in turn, may have contributed to lower quality of work, moreover, worse communication between co-workers which lowered the effectiveness of their work. Companies were losing their financial liquidity due to delayed settling of invoice payments, which resulted in "payment hold-ups". Businesses were unable to settle payments for bank loans, leasing arrangements or other debts on time. The value of euro increased, which brought on an increase in fuel expenses abroad. Due to sanitary inspections, border crossings had increased traffic, which contributed to delayed deliveries and goods collection. Yet another result of the pandemic was the decreased demand for transport services caused by the fact that production companies in the automotive, electronics and paper industries were either temporarily closed or operated in a slower mode. This resulted in less transport contracts, lower prices, less demand for drivers and decreased interest in leasing arrangements with TFL companies. The sales of semi-trailers and tractors dropped. Expenses for investments were limited.

Yet, the fact that at the peak of the pandemic the majority of transport companies were forced to suspend their activity or limit it, close the business or change the sector of operation into the national market was the most painful phenomenon.

In reference to the thesis put forward in the Introduction on the complexity and lack of uniformity in the coronavirus influence on the functioning of companies, the author would like to devote several sentences to the positive aspects of COVID-19 in relation to transport and logistics. Its impact is quite unique, since it does not work immediately or behaviourally to improve the condition of a company, but occurs as a process which accelerates or revives modern trends in the TFL economy.

It has already been mentioned that Galloway, in his book, claimed that the good aspects of the pandemic seem comparable with the bad ones. Americans, practically from one day to the next, have begun to save more and pollute the environment less. And while the author may have gotten slightly carried away due to his imagination, the conviction that the world will change after the pandemic should stand. It will not be the only thing to change, either. Our mentality will change. The TFL sector will be different, modernized, striving after the automation of transport processes. The digitalization of companies will become a priority. In Poland, the pandemic has instigated a digitization on 
an unprecedented scale. Both companies and offices are currently undergoing digitization. The situation contributed to the application of new solutions in document circulation. Companies have turned to e-documentation, e-signature, the automation of some processes has increased. Documents are more and more often sent via electronic mail, which greatly facilitates settling accounts with clients.

The phenomenon is observed mostly by foreign researchers. The authors in the Journal of Business Research also discuss the issue (Amankwah-Amoah et al. 2021). They perceive COVID-19 as "the great accelerator" in the quick tracking of the current global tendency to use modern developing technologies that introduce changes to lifestyle, models of work and business strategies. Therefore, COVID-19 has become a peculiar catalyst in the process of adapting the growing use of digitization in work organisation and in offices, simultaneously presenting the predictable and unpredictable opportunities, challenges and costs as a negative and positive feedback (feedback loop). The authors emphasise that adapting the rising technologies may be hindered by outside businesses, nostalgia, employer opportunism and negative influences on the well-being of employees, decreasing their efficiency, the balance between their private and professional life as well as their future of work. Moreover, digitization potentially increases the flexibility of employers and employees, reduces the energy used for long commutes and the wastage of time, but also evokes mistrust towards new forms of technological surveillance of employees and the colonisation of their free time (Hodder, 2020).

On the other hand, companies have gained new possibilities in terms of digitization, since the costs of communication, data storage and computers/ devices decreased. Digitization may make it possible for organisations to improve their functioning and increase competitiveness on the market.

The COVID-19 pandemic has completely transformed the Polish TFL market. On the one hand, it contributed to the dynamic growth of e-commerce, even creating some opportunities for development and, on the other, forced enterprises to adapt to the changing reality.

\section{The responses of companies to the pandemic crisis}

On the basis of the Eurologistics survey (Rynek Logistyczny..., 2021), logistics companies took the following actions to ensure the continuity of operations during the pandemic:

- sending some employees on leave $-47 \%$,

- limited use of outside entities: carriers, storemen, etc. - 39\%, 
- withdrawing a part of the vehicle pool from use $-39 \%$,

- lowering pay rates $-29 \%$,

- offering bonuses for readiness for work - $28 \%$,

- dismissing some employees - $18 \%$,

- extending working hours (overtime)- $14 \%$.

TFL companies, similarly to other institutions, have been subjected to unusual means restricting direct contact. The mobility restriction ("stay at home") applied to the citizens of almost all countries in the world. Companies have introduced restrictions limiting the contact of their own employees with employees of other companies, couriers, mailmen. Space was often divided into sections for a company's own employees and outside workers. The anxiety caused by COVID-19 was to be alleviated by remote working, dividing the employees into those on workplace-bound duty and those fulfilling their professional obligations by working from home.

The issue of working from home is not new. It was already happening earlier, although nowhere nearly as often as during the pandemic. Its superiority over workplace-bound work is debatable. The assessment of this type of employment appears rightfully questionable (Skurewicz, 2020). Aside from the few cases when working from home provides an opportunity to focus better and perform tasks faster and more diligently, there is fear that it generally involves more distractions and chances to lose concentration. Work in TFL companies is highly interactive and requires frequent contact with numerous people. It involves more teamwork than individual actions. Even the most efficient and effective work from home makes it impossible to complete all the necessary tasks. The change in the nature of work from workplace-bound to remote results in the employees' performing their tasks with decreased effectiveness.

In this context, the article by Malhotra (2021) should be mentioned, discussing the future of work in a post-pandemic world. In the author's opinion, enterprises will face new challenges, brought on by the circumstances surrounding the COVID-19 pandemic. They will have to create and maintain the organisation culture, understood as set of social norms and value systems, a correct organisational atmosphere and behavioural requirements. In this case, the maintenance of organisation culture signifies, among other things, the integration of employees, the understanding of the mission and strategy of organisation, creating a common language and the avoidance of conflicts as well as negative emotions (Lazarowicz, 2018). The creation of organisation culture in an environment where employees work from home has its difficulties. The author reasonably wonders, for instance, how is it possible to create and maintain 
organisation culture if many employees are independent agents. It is difficult to determine both the role of organisation culture during remote meetings and the degree of trust among the employees.

Organisational identification is a key challenge in an environment of remote working (Wiesenfeld et al. 2001). The term refers to the inclination of a member of an organisation to identify with the organisation, striving for the same goals, missions and values. The fulfilment of this postulate is not easy, since it depends on the employer, the employees, their individual needs and aspirations.

The central element of organisation culture is the motivation to work. Experts suggest that motivation theories for future work need to be re-examined. Theories regarding the future of work should concentrate not only on the external motivation (pay for work), but also on the internal motivation. This means that an employee should feel that the work done is important for the company and the management. Aside from the challenges enumerated above, there will be a need to monitor the efficiency of work of the employees working from home (for example, the Uber application will rely more and more on algorithms to efficiently associate workers with their jobs, monitor their efficiency and determine their pay [Malhotra, 2021]), to maintain balance between private and professional life and to use feedback (receive feedback via algorithms).

Additional steps undertaken included the necessity of wearing masks, maintain distance (of minimum 2 metres) between employees and install plexiglass dividers in the workstations. Moreover, a special room was designated for drivers to receive transport documentation and settle accounts after returning from work trips. Some companies (medium and large), despite the general predictions, invested in expanding the vehicle pool, due to advantageous offers from the lessors.

Some actions undertaken involved the change in the scope of logistics services (from the international to the national market), decreasing the vehicle pool and closing down micro-companies and small companies in the TFL sector, which may contribute to the increase in the supply of transport commissions in the future (after the pandemic), when the restoration of the economy will begin.

\section{Conclusion}

Our confidence in the validity and credibility of the theses put forward in the Introduction has been reinforced by the survey material (collected data) presented and discussed above, as well as by the author's own observation as a witness of and participant in the developments and changes taking place in the TSL 
sector during the pandemic, by data from GUS (Central Statistical Office) and EUROSTAT and the literature on the subject in both Polish and other languages. The coronavirus was especially destructive and negative at its peak (spring of 2020). The current situation is different. The pandemic-related phenomena are dynamic, they change and transform, while their strength and scope decreases with time. Companies take specific adaptive actions by adjusting their functioning to the circumstances brought on by the crisis.

The effects of the pandemic have not only been negative. Its positive impact consists in not merely contributing to certain changes, but more so in accelerating trends that have become clearly visible by now. Overcoming a crisis is neither a quick, nor an easy process for companies. It is determined by multiple factors, such as, for instance, the size of the company, its nature and specialty, scope, funds and other aspects.

Other determinants that play an important role are factors of a geopolitical nature. Among these, it is worth mentioning Brexit and the accompanying necessity of dealing with customs and tax administration in trade with Great Britain or the need to implement the Mobility Package. The functioning of a firm is therefore dependent on a number of factors, among which the pandemic, admittedly, represents a vital factor in shaping particular enterprises, but not the only one rather only one of many, though in certain cases it may be the deciding factor.

On the basis of the data presented above it can be seen that TSL companies are very vulnerable to fluctuations in the economic situation. While manufacturing companies (the car industry, electrical industry etc.) stopped production as a result of the pandemic, in the TSL sector the need for transport services decreased. The reduced demand for freight traffic forced transport firms to bring about changes in their supply of services (from the international to the domestic market), reduce the number of their employees, limit their services (withdrawing part of the vehicle pool from use) or close down their firms. The data obtained in the research are therefore not exclusively the result of the effect of the pandemic but also of a number of other factors which have been mentioned above.

Economic slowdown has an enormous effect on the TSL sector in Poland. The diminishing supply and demand for consumer goods influences the transportation and logistics market, for manufacturing companies produce fewer goods, which, in turn, leads to a reduction in the number of orders to be processed. Demand for transportation services falls and fewer goods are stored in warehouses. Thus the supply chain is depleted and this, in turn, has an impact on the state of transportation and logistics firms and their contribution to GDP. 
When considered from the positive side, COVID-19 in the TSL sector has been a factor speeding up innovation and creating new trends in logistics, including such phenomena as process robotization and automation, remote work, digitalization and e-commerce. These trends could revolutionize the industry.

In view of this, it would be advisable to take specific steps to accelerate the positive processes beginning to take place in the TSL economy and implement them into everyday practice so that they could become a tool to support the development of firms by increasing their efficiency.

A vital issue in connection with this is the need to raise awareness (knowledge and skills) among TSL employees about the use of modern technology. This requirement could be achieved in the following ways:

- develop and implement a national programme for the development of digital competences among employees of transport and freight forwarding companies,

- review the primary, secondary and tertiary education systems with a view to enhancing the content relating to digital competences,

- ensure internet access for the majority of households,

- make access to education readily available to adults as well as to children and adolescents.

- conduct empirical research with a view to gaining some confirmation of whether the COVID-19 crisis did, in fact, have a direct or indirect impact on the decisions of logistics companies to implement progressive solutions and technology to overcome the crisis.

It is worth introducing the views of a famous American professor and entrepreneur, Scott Galloway (2021), described in his newest publication Post corona. Biznes w czasach pandemii at the end. (original title: Post Corona: From Crisis to Opportunity). His optimistic attitude towards the pandemic is brought on by two basic observations: firstly, from the long-term perspective, the pandemic has functioned mostly as an accelerator of changes. Although it will initiate some occurrences and reverse others, its main effect will be the acceleration of processes already ongoing in the society. Secondly, each crisis carries opportunities. In fact, the deeper and more wide-spread it is, the bigger the opportunities. The author writes that the first observation weakens his enthusiasm towards the second, as many trends that have intensified as a result of the pandemic are negative in nature and restrict the possibilities of restoration and prosperity, which can occur in the post-pandemic reality (Galloway, 2021).

The general mechanism of the influence of the pandemic on economy described by Galloway appears correct. Although he refers to American experiences and exemplifies them, they also appear applicable to other countries. However, 
some of Galloway's statements, especially the two claiming that the good sides of the pandemic balance out its bad sides and that each crisis carries with it opportunities for development are debatable, can be considered controversial and evoke criticism. These theses may be too bold, yet cannot be rejected completely.

\section{Streszczenie}

Głównym zamierzeniem artykułu jest próba przedstawienia na podstawie istniejących badań sondażowych (ankiet i wywiadów), literatury przedmiotu, materiałów internetowych oraz własnych doświadczeń i obserwacji jako pracownika międzynarodowej firmy transportowo-logistycznej, ogólnych danych dotyczących wpływu pandemii na działalność przedsiębiorstw z branży TSL (Transport, Spedycja, Logistyka) oraz reakcji firm wobec pandemicznego kryzysu. Podejmując powyższą problematykę, autorka wychodzi z ogólnego założenia, że wpływ koronawirusa na funkcjonowanie firm $\mathrm{z}$ branży TSL był niejednorodny. I choć bezsprzecznie dominuje negatywne, destrukcyjne jego działanie, i jest ono najbardziej widoczne i odczuwalne, to jednak nie wyklucza się jego pozytywnego wpływu, jako czynnika przyśpieszającego i ożywiającego rozwój firm.

\section{Słowa}

klucze: $\quad$ pandemia, COVID-19, branża TSL, kryzys pandemiczny, destrukcyjny i konstruktywny wptyw.

\section{Summary}

The article attempts to present, on the basis of the existing survey research (questionnaires and interviews), subject literature, internet data as well as personal experiences and observations of the author (an employee of an international transport and logistics company), the general data regarding the influence of the COVID-19 pandemic on the functioning of transport, freight forwarding and logistics companies (referred to as TFL companies) and, additionally, the responses of these companies to the pandemic crisis. The choice of this subject was made on the general assumption that the influence of the coronavirus pandemic on the functioning of TFL companies has not been uniform. And 
although, unquestionably, its most perceptible, negative and destructive force predominates, the existence of a positive impact, as a factor that accelerates and revives company development, is not impossible.

Keywords: $\quad$ pandemic, COVID-19, TFL companies, pandemic crisis, destructive and constructive impact.

\section{References}

Amankwah-Amoah, J., Khan Z., Wood G., Knight G. (2021). COVID-19 and digitalization: The great acceleration, Journal of Business Research 136. Argouleas, E. (2009). The Global Credit Crisis, Behavioural Finance, and Financial regulation. Research of a New Orthodoxy. Journal of Corporate Law Studies, 9 (6).

Babczyński, B.(n.d.).Kryzys.Szansanarozwój?https:/ / wuplodz.praca.gov.pl /documents/58203/845677/Kryzys\%20-\%20szansa\%20na\%20rozw\%C3\% B3j. pdf/787f179c-5a39-43f2-b4fa-023860eba708?t=1406797353000 (25.09.2021access date).

Banasiak, K. (2010). Modele kryzysów walutowych. Ekonomika i Organizacja Gospodarki Żywnościowej.

Bordo, M., Eichengreen, B., Klingebiel, D., Martinez-Peria, M. (2001). Is the crisis problem growing more severe? Economic policy, 16 (32), pp. 52-82.

Czech, K., Karpio, A., Wielechowski, M., Woźniakowski, T., ŻebrowskaSuchodolska, D. (2020). Polska gospodarka w początkowym okresie pandemii COVID-19, Warszawa: Wydawnictwo SGGW, pp. 9-16.

Duszyński, J., Afelt, A., Ochlab-Marcinek, A., Owczuk, R., Pyre, K., Rosińska, M., Rychard, A., Smiatacz, T. (2020) Zrozumieć COVID-19. Opracowanie zespotu ds. COVID-19 przy Prezesie Polskiej Akademii Nauk. Warszawa: PAN.

Eurologistics, https://log24.pl/wydania_pdf/Sonda_Eurologistics_ covid_19.pdf, (20.04.2021- access date).

Galloway, S. (2021). Post Corona, Biznes w czasach pandemii, od kryzysu do szans, Translation: Witkowska, M. Warszawa: MT Biznes.

Ganiec, M. (Ed.). (2020). Koronawirus rozdaje karty. TSL Biznes, 4/2020 (112), pp. 10-12. https://tsl-biznes.pl/online/TSLbiznes_2020_04.pdf (02.06.2021 - access date).

Gerrig, J.R., Zimbardo, G.P. (2006). Psychologia i życie. Warszawa: Wydawnictwo Naukowe PWN.

Hodder, A. (2020). New Technology, Work and Employment in the era of COVID-19. Reflecting on legacies of research. New Technology, Work and Employment, 35. 
Hordecka, A. (2017). Polityka gospodarcza w świetle przemian współczesnej myśli ekonomicznej. Perspektywy polityki gospodarczej, Praca zbiorowa pod redakcją Janusza Stacewicza, 90, Warszawa: Prace i Materiały Instytutu Rozwoju Gospodarczego SHG.

Kiełczewski, D. (2021). Pandemia COVID-19 w perspektywie ekonomii złożoności, Białystok: Uniwersytet w Białymstoku.

Lazarowicz, A. Jaki znaczenie dla firmy ma kultura organizacyjna? https:// poradnikprzedsiebiorcy.pl/-jakie-znaczenie-dla-firmy-ma-kulturaorganizacyjna (25.09.2021 - access date).

Malhotra, A. (2021). The Postpandemic Future of Work, Journal of Management, Vol. 47 No. 5.

Mruk, H. (2018). Ekonomia behawioralna a skuteczność zarządzania. Studia i prace. Kolegium Zarzadzania i Finansów SGH. Issue (167), pp. 9-19.

Pandemia - skutki ekonomiczne i społeczne, Przegląd Ekonomiczny No. 20/2020.

Płużek, Ż. (1991). Psychologia pastoralna. Kraków: Instytut Teologiczny Księży Misjonarzy.

Polski, mikro, mały i średni biznes w obliczu pandemii COVID-19. Przychody, płynność i reakcje na wstrzas, PWC, https://www.pwc.pl/pl/pdf/polskimikro-maly-sredni-biznes-w-obliczu-pandemii.pdf (30.04.2021 - access date).

Ranking firm TSL - 24. (2019). DGP Event.

Ranking firm TSL - 25. (2020). DGP Event.

Ranking firm TSL - 26. (2021). DGP Event.

Reinhart, C.M., Rogoff, K.S. (2008). This time is different: A panoramic view of eight centuries of financial crises. National Bureau of Economics Research. NBER working papers, 13882.

Rothbard, M.N. (2010). Wielki kryzys w Ameryce. Kraków: Instytut Ludwika von Misesa.

Rynek logistyczny $w$ dobie pandemii COVID-19 (Sondaż), Eurologistics. https:// /og24.pl/wydania_pdf/Sonda_Eurologistics_covid_19.pdf (20.04.2021 - access date).

Shaikh, A. (1978). An introduction to the history of crisis theories. US capitalism in crisis. Published by the Economics Education Project of The Union for Radical Political Economics.

Szlagura, W. (n.d.). Rzeczywistość kryzysu - pojęcie, definicja, teorie, dynamika. http://www.interwencjakryzysowa.pl/rzeczywistosc-kryzysu-pojeciedefinicje-teorie-dynamika, (20.09.2021- access date).

Transport przyszłości. Raport o perspektywach rozwoju transportu drogowego $w$ Polsce w latach 2020-2030. Opracowany przez PWC na zlecenie ze Zwiazkiem Pracowdawców Transport i Logistyka Polska. (2019). https://tlp.org.pl/wpcontent/uploads/2019/09/pwc-transport-przyszlosci-web.pdf (17.09.2021 - access date). 
Transport - wyniki działalności w 2020r., zespół autorski pod kierunkiem Katarzyny Dmitrowicz, GUS i US, Warszawa i Szczecin, 2020r.

Webster's Encyclopedic Dictionary od the English Language. (1957). New York. Wiesenfeld, B.M., Raghuram, S., Garud, R. (2001). Organizational identification among virtual workers: The role of need for affiliation and perceived work-based social support. Journal Management.

Włodarczyk, E. (2011). Klęska żwyiołowa lub ekologiczna. Czyli o tym, że statystyka nie dotyka tego, co jest wewnątrz. In: Włodarczyk, E., Cytlak, I. (Eds) Cztowiek wobec krytycznych sytuacji życiowych. Z teorii i praktyki pracy socjalnej. Poznań: Wydawnictwo Naukowe UAM.

Wolak, M. (Ed.). (2019). Rewolucja technologiczna. Kierunki rozwoju branży TSL. Polski Instytut Transportu Drogowego.

Zygan, M. (2013). Ekonomia behawioralna - wprowadzenie do problematyki, Studia i prace Wydziału Nauk Ekonomicznych Nr 32, Uniwersytet Szczeciński.

Zysińska, M. (2019). Ocena przedsiębiorstw TSL działających w Polsce - dylematy metodyczne badań, Studia i Prace, Kolegium Zarządzania i Finansów. Issue 173/2019. Oficyna Wydawnicza SGH. 